\title{
Growth Suppression as a Control for Nectarine Pox
}

Tara Auxt Baugher

West Virginia University Experiment Farm, Kearneysville, WV 25430

\author{
Stephen S. Miller \\ Appalachian Fruit Research Station, U.S. Department of Agriculture- \\ Agricultural Research Service, Kearneysville, WV 25430
}

Additional index work. Prunus persica, fruit disorder, growth regulation, paclobutrazol, girdling, root pruning, summer pruning

\begin{abstract}
A 2-year study was designed to test the effect of four growth-suppressing treatments on the incidence of nectarine [Prunus persica $($ L.) Batsch] pox, nectarine fruit quality, and the growth and nutritional status of nectarine trees. Root pruning was the only treatment that significantly reduced the incidence of nectarine pox. The percentage of red surface was increased by root pruning, foliar-applied paclobutrazol, and girdling. Root pruning and paclobutrazol suppressed extension shoot growth. Root pruning decreased fruit $\mathrm{N}, \mathrm{P}, \mathrm{K}, \mathrm{Mg}, \mathrm{Mu}, \mathrm{Fe}, \mathrm{B}$, and $\mathrm{Zn}$ levels and increased fruit Ca. Results of the study support earlier observations that nectarine pox is associated with excessive shoot growth, excessive levels of fruit $\mathbf{N}$ and $\mathrm{K}$, and low levels of fruit Ca. Chemical name used: Beta-[ (4-chlorophenyl) methyl] -alpha-(1,1-dimethylethyl)-lH-1,2,4 -triazole-l-ethanol (paclobutrazol).
\end{abstract}

Nectarine pox is a disorder characterized by superficial warty outgrowths that reduce packout of commercially grown fruit. It has been observed in most peach-growing regions and on many cultivars, but it was not described in the literature until 1991 (Baugher and Miller, 1991). Expression of the disorder has been associated with excessive shoot growth, excessive levels of $\mathrm{N}$ and $\mathrm{K}$, and low levels of B or Ca (Baugher and Miller, 1991).

Studies were initiated in 1985 in a block of nectarine trees where pox was observed on $10 \%$ to $50 \%$ of the fruit in some years. During 1985-87, attempts were made to ameliorate the condition with application of $\mathrm{B}$ to soil or foliage. Nectarine pox was significantly reduced by a petal fall spray of soluble $\mathrm{B}$ in one of the three seasons, but in general the results were inconsistent (T.A.B., unpublished). Subsequent experiments were designed to test the effects of reduced tree vigor on nectarine pox.

It has been shown that length of peach and nectarine shoot internodes is reduced by foliar sprays of paclobutrazol (Blanco, 1988; George and Nissen, 1987). Girdling decreases shoot extension growth while increasing fruit size and advancing maturity (Dann et al., 1984; Femandez-Escobar et al., 1987). Root pruning suppresses shoot growth on apple trees (Ferree, 1989; Schupp and Ferree, 1988). Vegetative responses of peach

Received for publication 15 Nov. 1990. Approved for publication by the Director, West Virginia Agr. and For. Expt. Station as Scientific Article no. 2254. We thank Ronald Slonaker, David Leach, Sandra Walter, Joe Eldridge, and Larry Crim for their contributions to this study. The cost of publishing this paper was defrayed in part by the payment of page charges. Under postal regulations, this paper therefore must be hereby marked $a d$ vertisement solely to indicate this fact.

trees to summer pruning are varied, but some studies show that summer pruning reduces dry weight accumulation and secondary growth (Hayden and Emerson, 1984; Marini and Rossi, 1985; Rom and Ferree, 1985).

The present study was designed to test the effect of foliar applications of paclobutrazol, girdling, root pruning, and summer pruning on the incidence of nectarine pox. Secondary objectives were to investigate treatment effects on the nutritional status and growth of nectarine trees and on fruit size and color.

The experiment was conducted during 1988 and 1989 in a 1-ha commercial block of 'Firebrite' nectarines, planted in 1982 on a deep, well-drained, and fertile Hagerstown/ Frederick cherty silt loam soil (fine, mixed, mesic Typic Hapludalf) in Kearneysville, W.Va. Trees were vigorous and growth was considered excessive compared with other blocks where nectarine pox was less common. Treatments in 1988 included: 1) root tree growth. percentages. Eight replicates per treatment.

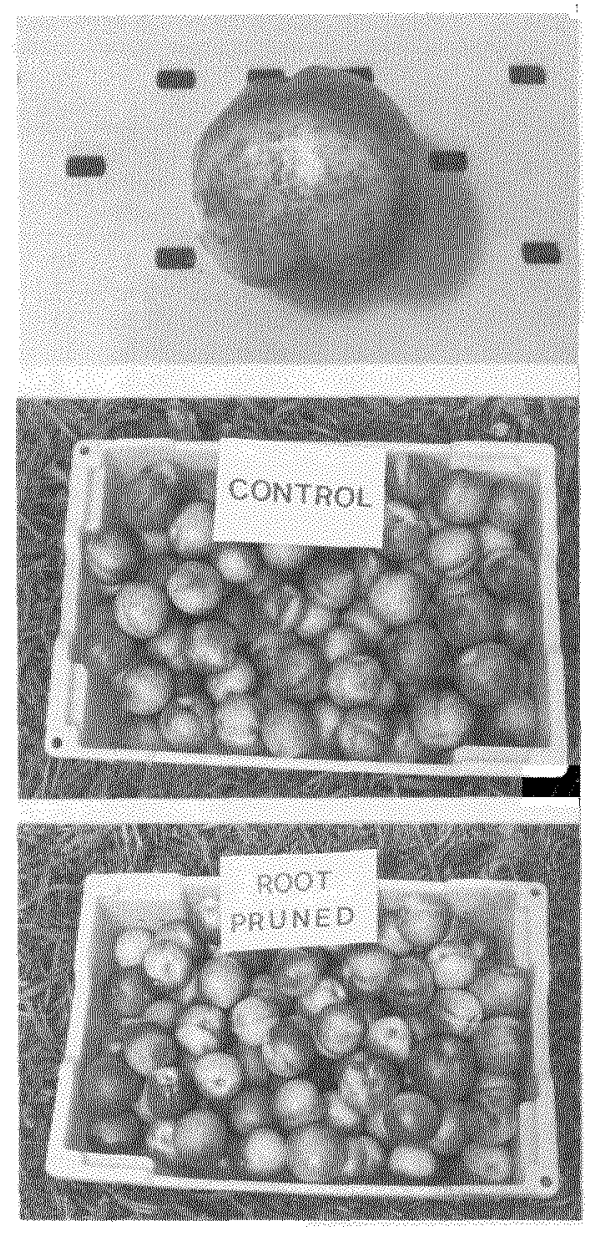

Table 1. Influence of growth-suppressing treatments on incidence of nectarine pox, fruit quality, and

\begin{tabular}{|c|c|c|c|c|c|}
\hline \multirow[b]{2}{*}{ Treatment } & \multirow{2}{*}{$\begin{array}{c}\text { Nectarine pox } \\
(\%)\end{array}$} & \multirow{2}{*}{$\begin{array}{c}\text { Red } \\
\text { surface } \\
(\%)\end{array}$} & \multirow{2}{*}{$\begin{array}{l}\text { Fruit diam } \\
\qquad(\mathrm{cm})\end{array}$} & \multicolumn{2}{|c|}{ Shoot length $(\mathrm{cm})$} \\
\hline & & & & Vertical & Horizontal \\
\hline & & & 1988 & & \\
\hline Root pruning & $4.1 \mathrm{a}^{z}$ & $89 a$ & $6.1 \mathrm{~b}$ & 59 a & 32 a \\
\hline Paclobutrazol & $4.3 \mathrm{a}$ & $81 \mathrm{~b}$ & $6.4 \mathrm{a}$ & $101 \mathrm{~b}$ & $44 \mathrm{~b}$ \\
\hline Limb girdling & $3.4 \mathrm{a}$ & $80 \mathrm{~b}$ & $6.3 \mathrm{a}$ & $96 \mathrm{~b}$ & $46 \mathrm{~b}$ \\
\hline Summer pruning & $2.8 \mathrm{a}$ & $83 b$ & $6.3 \mathrm{a}$ & $87 \mathrm{~b}$ & $39 \mathrm{ab}$ \\
\hline \multirow[t]{2}{*}{ Untreated control } & $3.5 \mathrm{a}$ & $80 \mathrm{~b}$ & $6.4 \mathrm{a}$ & $100 \mathrm{~b}$ & $44 \mathrm{~b}$ \\
\hline & & & 1989 & & \\
\hline Root pruning (1989) & $5.5 \mathrm{a}$ & $79 a b$ & $6.8 \mathrm{a}$ & $82 \mathrm{ab}$ & 32 a \\
\hline Root pruning (1988) & $4.4 \mathrm{a}$ & 84 a & $6.8 \mathrm{a}$ & $87 \mathrm{bc}$ & $32 \mathrm{a}$ \\
\hline Paclobutrazol & $8.1 \mathrm{ab}$ & $80 a b$ & $6.9 \mathrm{a}$ & $78 \mathrm{a}$ & 31 a \\
\hline Limb girdling & $10.8 \mathrm{~b}$ & $76 \mathrm{~b}$ & $7.0 \mathrm{a}$ & $95 \mathrm{c}$ & $37 \mathrm{~b}$ \\
\hline Untreated control & $11.5 \mathrm{~b}$ & $70 \mathrm{c}$ & $6.9 \mathrm{a}$ & $105 \mathrm{~d}$ & $38 \mathrm{~b}$ \\
\hline
\end{tabular}

${ }^{2}$ Mean separation within column and year by LSD, $P=0.05$. Square root transformation performed on data expressed as small whole numbers and arcsin transformation performed on data expressed as 
Table 2. Influence of growth-regulation treatments on nectarine foliar and fruit nutrient levels.

\begin{tabular}{|c|c|c|c|c|c|c|c|c|c|c|}
\hline \multirow{3}{*}{$\begin{array}{l}\text { Treatment } \\
\text { and year }\end{array}$} & \multicolumn{10}{|c|}{ Nutrient levels } \\
\hline & $\mathrm{N}$ & $\mathrm{P}$ & $\mathrm{K}$ & $\mathrm{Ca}$ & $\mathrm{Mg}$ & $\mathrm{Mn}$ & $\mathrm{Fe}$ & $\mathrm{Cu}$ & B & $\mathrm{Zn}$ \\
\hline & \multicolumn{5}{|c|}{$\%$} & \multicolumn{5}{|c|}{$\mathrm{ppm}$} \\
\hline \multicolumn{6}{|l|}{1988} & \multicolumn{5}{|c|}{ Leaf } \\
\hline Root pruning & $3.84 \mathrm{a}^{2}$ & $0.22 \mathrm{a}$ & $2.94 \mathrm{a}$ & $2.64 \mathrm{a}$ & $0.63 \mathrm{a}$ & $102.0 \mathrm{a}$ & $147 \mathrm{a}$ & $8.25 \mathrm{a}$ & $35.7 \mathrm{ab}$ & $19.0 \mathrm{a}$ \\
\hline Paclobutrazol & $3.96 \mathrm{a}$ & $0.24 \mathrm{a}$ & $2.96 \mathrm{a}$ & $2.51 \mathrm{a}$ & $0.63 \mathrm{a}$ & $96.2 \mathrm{a}$ & 144 a & $9.25 \mathrm{a}$ & $39.7 \mathrm{a}$ & $20.5 \mathrm{a}$ \\
\hline Limb girdling & $3.84 \mathrm{a}$ & $0.24 \mathrm{a}$ & $3.08 \mathrm{a}$ & $2.71 \mathrm{a}$ & $0.68 \mathrm{a}$ & $114.5 \mathrm{a}$ & $150 \mathrm{a}$ & $9.00 \mathrm{a}$ & $38.0 \mathrm{ab}$ & $20.2 \mathrm{a}$ \\
\hline Summer pruning & $3.85 \mathrm{a}$ & $0.23 \mathrm{a}$ & $2.72 \mathrm{a}$ & $2.65 \mathrm{a}$ & $0.67 \mathrm{a}$ & $94.0 \mathrm{a}$ & 139 a & $8.75 \mathrm{a}$ & $35.0 \mathrm{~b}$ & $20.0 \mathrm{a}$ \\
\hline \multirow[t]{2}{*}{ Untreated control } & $3.84 \mathrm{a}$ & $0.22 \mathrm{a}$ & $2.94 \mathrm{a}$ & $2.64 \mathrm{a}$ & $0.63 \mathrm{a}$ & $102.0 \mathrm{a}$ & $147 \mathrm{a}$ & $8.25 \mathrm{a}$ & $35.7 \mathrm{ab}$ & 19.0 a \\
\hline & \multicolumn{10}{|c|}{ Fruit flesh } \\
\hline Root pruning & $0.78 \mathrm{~b}$ & $0.097 \mathrm{~b}$ & $1.48 \mathrm{~b}$ & $0.028 \mathrm{a}$ & $0.048 \mathrm{a}$ & $3.19 \mathrm{a}$ & $22.6 \mathrm{a}$ & $0.550 \mathrm{a}$ & $8.7 \mathrm{~b}$ & $3.91 \mathrm{~b}$ \\
\hline Paclobutrazol & $1.10 \mathrm{a}$ & $0.125 \mathrm{a}$ & $1.67 \mathrm{a}$ & $0.029 \mathrm{a}$ & $0.053 \mathrm{a}$ & $3.95 \mathrm{a}$ & $27.1 \mathrm{a}$ & $0.650 \mathrm{a}$ & $12.2 \mathrm{~b}$ & $6.22 \mathrm{a}$ \\
\hline Limb girdling & $1.10 \mathrm{a}$ & $0.125 \mathrm{a}$ & $1.77 \mathrm{a}$ & $0.028 \mathrm{a}$ & $0.054 \mathrm{a}$ & $4.01 \mathrm{a}$ & $27.6 \mathrm{a}$ & $0.887 \mathrm{a}$ & $13.0 \mathrm{a}$ & $3.92 \mathrm{ab}$ \\
\hline Summer pruning & $1.04 \mathrm{a}$ & $0.117 \mathrm{a}$ & $1.72 \mathrm{a}$ & $0.027 \mathrm{a}$ & $0.052 \mathrm{a}$ & $3.46 \mathrm{a}$ & $23.5 \mathrm{a}$ & $0.562 \mathrm{a}$ & $11.1 \mathrm{~b}$ & $4.65 \mathrm{ab}$ \\
\hline \multirow[t]{2}{*}{ Untreated control } & $1.06 \mathrm{a}$ & $0.126 \mathrm{a}$ & $1.75 \mathrm{a}$ & $0.027 \mathrm{a}$ & $0.054 \mathrm{a}$ & $4.44 \mathrm{a}$ & $31.1 \mathrm{a}$ & $0.587 \mathrm{a}$ & $13.4 \mathrm{a}$ & $5.72 \mathrm{ab}$ \\
\hline & \multicolumn{10}{|c|}{ Fruit peel } \\
\hline Root pruning & $1.44 \mathrm{~b}$ & $0.099 \mathrm{a}$ & $1.44 \mathrm{~b}$ & $0.099 \mathrm{a}$ & $0.074 \mathrm{a}$ & $6.49 \mathrm{~b}$ & $22.1 \mathrm{a}$ & $0.575 \mathrm{a}$ & $15.2 \mathrm{a}$ & $6.45 \mathrm{a}$ \\
\hline Paclobutrazol & $1.52 \mathrm{ab}$ & $0.115 \mathrm{a}$ & $1.52 \mathrm{ab}$ & $0.115 \mathrm{a}$ & $0.079 \mathrm{a}$ & $7.66 \mathrm{ab}$ & $21.0 \mathrm{a}$ & $0.712 \mathrm{a}$ & $18.0 \mathrm{a}$ & $7.66 \mathrm{a}$ \\
\hline Limb girdling & $1.53 \mathrm{ab}$ & $0.097 \mathrm{a}$ & $1.53 \mathrm{ab}$ & $0.097 \mathrm{a}$ & $0.076 \mathrm{a}$ & $7.39 \mathrm{ab}$ & $18.0 \mathrm{a}$ & $0.612 \mathrm{a}$ & $16.4 \mathrm{a}$ & $5.39 \mathrm{a}$ \\
\hline Summer pruning & $1.60 \mathrm{a}$ & $0.123 \mathrm{a}$ & $1.60 \mathrm{a}$ & $0.123 \mathrm{a}$ & $0.082 \mathrm{a}$ & $8.05 \mathrm{ab}$ & $21.4 \mathrm{a}$ & $0.700 \mathrm{a}$ & $17.8 \mathrm{a}$ & $6.49 \mathrm{a}$ \\
\hline Untreated control & $1.61 \mathrm{a}$ & $0.101 \mathrm{a}$ & $1.61 \mathrm{a}$ & $0.101 \mathrm{a}$ & $0.082 \mathrm{a}$ & $8.77 \mathrm{a}$ & $23.7 \mathrm{a}$ & $0.625 \mathrm{a}$ & $18.2 \mathrm{a}$ & $7.79 \mathrm{a}$ \\
\hline \multicolumn{6}{|l|}{1989} & \multicolumn{5}{|c|}{ Leaf } \\
\hline Root pruning (1989) & $3.82 \mathrm{a}$ & $0.24 \mathrm{a}$ & $3.17 \mathrm{a}$ & $1.89 \mathrm{a}$ & $0.46 \mathrm{a}$ & $87.9 \mathrm{a}$ & 131 a & $10.0 \mathrm{a}$ & $32.0 \mathrm{a}$ & $17.3 \mathrm{a}$ \\
\hline ling (1988) & $3.62 \mathrm{a}$ & $0.24 \mathrm{a}$ & $2.91 \mathrm{c}$ & $1.83 \mathrm{a}$ & $0.47 \mathrm{a}$ & $84.3 \mathrm{a}$ & $117 \mathrm{a}$ & $8.9 \mathrm{a}$ & $31.0 \mathrm{a}$ & $18.6 \mathrm{a}$ \\
\hline Paclobutrazol & $3.86 \mathrm{a}$ & $0.23 \mathrm{a}$ & $2.83 \mathrm{c}$ & $1.92 \mathrm{a}$ & $0.46 \mathrm{a}$ & $85.5 \mathrm{a}$ & 109 a & $10.4 \mathrm{a}$ & $32.0 \mathrm{a}$ & $18.6 \mathrm{a}$ \\
\hline Limb girdling & $3.84 \mathrm{a}$ & $0.23 a$ & $2.94 b c$ & $1.90 \mathrm{a}$ & $0.44 \mathrm{a}$ & $79.5 \mathrm{a}$ & $135 \mathrm{a}$ & $10.3 \mathrm{a}$ & $31.0 \mathrm{a}$ & $17.8 \mathrm{a}$ \\
\hline \multirow[t]{2}{*}{ Untreated control } & $3.91 \mathrm{a}$ & $0.25 \mathrm{a}$ & $3.13 \mathrm{ab}$ & $1.82 \mathrm{a}$ & $0.45 \mathrm{a}$ & $84.8 \mathrm{a}$ & $133 \mathrm{a}$ & $10.0 \mathrm{a}$ & $32.0 \mathrm{a}$ & $20.4 \mathrm{a}$ \\
\hline & \multicolumn{10}{|c|}{ Fruit flesh } \\
\hline Root pruning (1989) & $0.84 \mathrm{c}$ & $0.166 \mathrm{c}$ & $1.46 \mathrm{~d}$ & $0.043 \mathrm{a}$ & $0.062 \mathrm{c}$ & $4.46 \mathrm{ab}$ & $21.4 \mathrm{~b}$ & $2.16 \mathrm{a}$ & $18.3 \mathrm{ab}$ & $13.2 \mathrm{a}$ \\
\hline ling (1988) & $0.86 \mathrm{c}$ & $0.180 \mathrm{~b}$ & $1.49 \mathrm{~cd}$ & $0.029 \mathrm{~d}$ & $0.062 \mathrm{c}$ & $4.26 \mathrm{~b}$ & $17.4 \mathrm{c}$ & $1.80 \mathrm{a}$ & $16.3 \mathrm{c}$ & $10.9 \mathrm{~d}$ \\
\hline Paclobutrazol & $1.02 \mathrm{~b}$ & $0.178 \mathrm{~b}$ & $1.57 \mathrm{~b}$ & $0.032 \mathrm{~b}$ & $0.063 \mathrm{bc}$ & $4.54 \mathrm{a}$ & $25.8 \mathrm{a}$ & $1.64 \mathrm{a}$ & $16.2 \mathrm{c}$ & $12.8 \mathrm{c}$ \\
\hline Limb girdling & $1.07 \mathrm{a}$ & $0.180 \mathrm{~b}$ & $1.50 \mathrm{c}$ & $0.032 \mathrm{~b}$ & $0.064 \mathrm{ab}$ & $4.48 \mathrm{ab}$ & $20.0 \mathrm{~b}$ & $1.70 \mathrm{a}$ & $17.7 \mathrm{~b}$ & $13.4 \mathrm{~b}$ \\
\hline \multirow[t]{2}{*}{ Untreated control } & $1.01 \mathrm{~b}$ & $0.190 \mathrm{a}$ & $1.62 \mathrm{a}$ & $0.030 \mathrm{c}$ & $0.065 \mathrm{a}$ & $4.46 \mathrm{ab}$ & $21.0 \mathrm{~b}$ & $2.52 \mathrm{a}$ & $18.7 \mathrm{a}$ & $14.0 \mathrm{a}$ \\
\hline & \multicolumn{10}{|c|}{ Fruit peel } \\
\hline Root pruning (1989) & $1.01 \mathrm{~d}$ & $0.150 \mathrm{c}$ & $1.47 \mathrm{~b}$ & $0.086 \mathrm{c}$ & $0.081 \mathrm{~b}$ & $7.60 \mathrm{ab}$ & $28.2 \mathrm{c}$ & $2.34 \mathrm{a}$ & $20.8 \mathrm{c}$ & $17.3 \mathrm{~b}$ \\
\hline Root pruning (1988) & $1.09 \mathrm{c}$ & $0.168 \mathrm{~b}$ & $1.58 \mathrm{a}$ & $0.085 \mathrm{c}$ & $0.082 \mathrm{~b}$ & $7.18 \mathrm{~b}$ & $27.6 \mathrm{c}$ & $2.94 \mathrm{a}$ & $19.8 \mathrm{~d}$ & $14.8 \mathrm{c}$ \\
\hline Paclobutrazol & $1.17 \mathrm{~b}$ & $0.170 \mathrm{~b}$ & $1.62 \mathrm{a}$ & $0.097 \mathrm{~b}$ & $0.086 \mathrm{a}$ & $7.76 \mathrm{ab}$ & $33.0 \mathrm{a}$ & $4.16 \mathrm{a}$ & $19.7 \mathrm{~d}$ & $13.0 \mathrm{~d}$ \\
\hline Limb girdling & $1.28 \mathrm{a}$ & $0.180 \mathrm{a}$ & $1.61 \mathrm{a}$ & $0.102 \mathrm{a}$ & $0.085 \mathrm{a}$ & $8.24 \mathrm{a}$ & $30.6 \mathrm{~b}$ & $3.72 \mathrm{a}$ & $21.3 \mathrm{~b}$ & $20.9 \mathrm{a}$ \\
\hline Untreated control & $1.17 \mathrm{~b}$ & $0.174 \mathrm{~b}$ & $1.62 \mathrm{a}$ & $0.085 \mathrm{c}$ & $0.085 \mathrm{a}$ & $7.40 \mathrm{ab}$ & $27.8 \mathrm{c}$ & $3.80 \mathrm{a}$ & $22.0 \mathrm{a}$ & $20.6 \mathrm{a}$ \\
\hline
\end{tabular}

${ }^{2}$ Mean separation within column, year, and type of tissue analysis by LSD, $P=0.05$. Arcsin transformation performed on data expressed as percentages or decimal fractions. Data are means of eight (1988) or five (1989) samples.

an untreated control. Based on growth responses in 1988, treatments were modified in 1989 (using new trees in the same block) and included: 1) root pruning at a distance of $90 \mathrm{~cm}$ from the trunk and a depth of 25 $\mathrm{cm}, 2)$ root pruning in 1988 only (treatment $1,1988)$, 3) paclobutrazol spray at 250 $\mathrm{mg} \cdot$ liter $^{-1}$ beginning $2 \mathrm{WAPF}$ and continuing at 14-day intervals for three additional sprays, 4) girdling each of four scaffolds per tree with a 5-mm "S" cut, and 5) an untreated control. Root pinning was performed on two sides of the trunk, between rows, 2 WAFB (Schupp and Ferree, 1988). Paclobutrazol was applied by hand gun to wet the foliage to drip. Trees were girdled 8 WAFB using methods described by Lipe (1988). Summer pruning entailed thinning cuts only made during the first week of May, June, and July. Treatments were applied to eight single-tree replicates in a randomized-block design.

Treatment effects in both years were compared using similar procedures. The incidence of nectarine pox was based on the inspection of 100 fruit per replicate sampled from the second harvest picking. Percentage of red surface $(0=$ no red; $100=$ red over
$100 \%$ of epidermis) was visually estimated and fruit diameter measured on 20 fruit per replicate (also at second harvest picking).

Ten vertical and five horizontal shoots per replicate, randomly selected from the upper one-third of the canopy, were measured in November following treatment. Change in trunk cross-sectional area (ATCSA) was determined from May 1988 to May 1989 and from May 1989 to May 1990. Leaves and fruit were collected for tissue analysis during the 3rd week of July of 1988 and 1989. Leaf, fruit flesh, and fruit peel nutrient levels were determined by ICP inductively coupled RF type plasma emission spectrophotometry. Data were subjected to analysis of variance for each year, and means were separated by the LSD test. Regression analysis was performed to investigate relationships between plant nutrient levels and the incidence of nectarine pox.

Effects on nectarine pox and tree performance. Field studies for control of nectarine pox have not been conducted previously because the incidence of the disorder varies widely among orchard blocks and growing seasons. During the 2 years of this study, the percentage of fruit (from control trees) exhibiting nectarine pox was $3 \%$ to $12 \%$, whereas the incidence in this block was as high as $80 \%$ before the studies were initiated. No differences in the incidence of nectarine pox were observed in 1988, but in 1989 both root pruning treatments significantly reduced the incidence of the disorder (Fig. 1; Table 1). The percentage red surface was significantly increased by root pruning in 1988 and by all modifications in 1989. Fruit diameter was reduced by root pruning at $60 \mathrm{~cm}$ in 1988; thus, the distance from the trunk was increased to $90 \mathrm{~cm}$ in 1989 . Diameter of the fruit was unaffected otherwise. Treatments had no effect on $\Delta$ TCSA (range $0.7-1.3 \mathrm{~cm}^{2}$ in $1988 ; 1.4-2.5 \mathrm{~cm}^{2}$ in 1989). Root pruning reduced shoot growth in 1988, and root pruning and paclobutrazol suppressed shoot growth in 1989.

Relationship of plant nutrient levels to nectarine pox. Previous indications (Baugher and Miller, 1991) that nectarine pox is influenced by plant nutrient levels are further supported by the results of this study (Table 2). Minimal differences in leaf nutrient levels were found, but several differences existed in fruit flesh and peel nutrient levels. Root pruning decreased fruit flesh and/or peel 


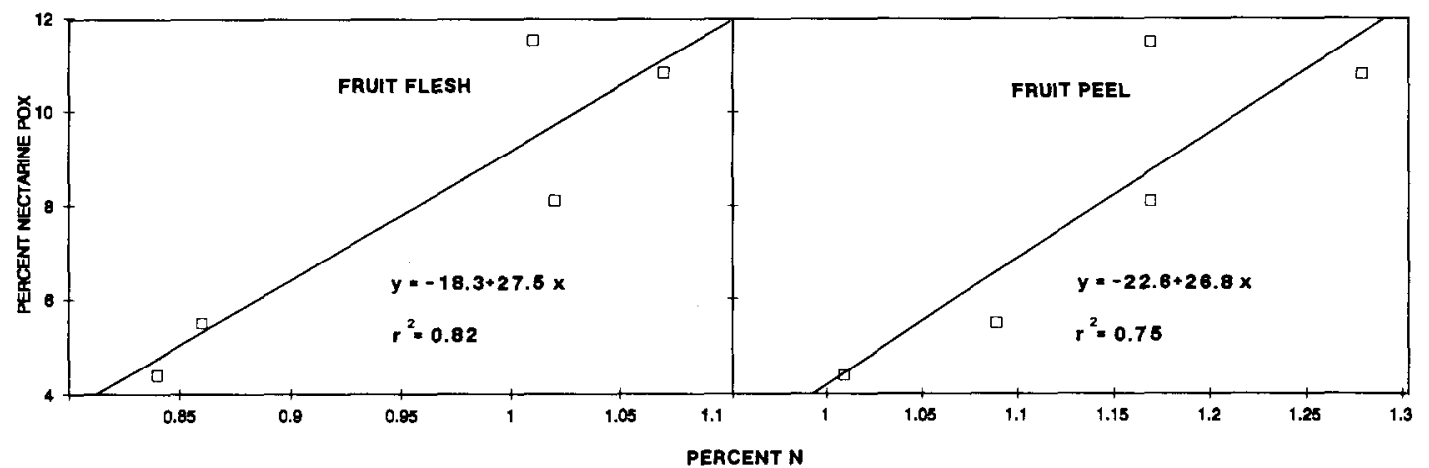

Fig.2. Relationships between the incidence of nectarine pox and percent $\mathrm{N}$ in fiuit flesh and fruit peel $(1989$ treatment means; $n=5, P=0.05)$.

$\mathrm{N}, \mathrm{P}, \mathrm{K}, \mathrm{Mg}, \mathrm{Mn}, \mathrm{Fe}, \mathrm{B}$, and $\mathrm{Zn}$ levels but increased fruit $\mathrm{Ca}$ relative to the control in 1988 and/or 1989. Effects from the other treatments were most obvious in 1989. Paclobutrazol sprays decreased the levels of $\mathrm{P}$, $\mathrm{K}, \mathrm{Mg}$, and $\mathrm{B}$; $\mathrm{N}$ was unaffected and $\mathrm{Ca}$ and Fe were increased. Girdling of scaffold limbs increased $\mathrm{N}, \mathrm{P}$, and $\mathrm{Ca}$ and decreased $\mathrm{B}$. With the exception of the decreased $\mathrm{B}$ levels, root pruning provided the most desirable effects on nectarine nutrient levels. Leaf nutrient levels were not correlated with the incidence of nectarine pox. However, there were positive correlations between fruit $\mathrm{N}$ levels and the incidence of the disorder (Fig. 2). Goodness-of-fit values were 0.82 and 0.75 for flesh $\mathrm{N}$ and peel $\mathrm{N}$, respectively $(P=$ 0.05).

Results of the current study support earlier observations and provide evidence that nectarine pox is likely to occur when trees are vigorous, levels of fruit $\mathrm{N}$ and $\mathrm{K}$ are high, and fruit $\mathrm{Ca}$ is low. How these conditions result in distinct and localized proliferation of the subepidermal fruit tissue is not apparent. Similar symptoms, i.e., superficial and distorted growth, are known to occur in other tree fruits but are associated with viruses (stony pit of pear, peach wart), fungi (plum pockets) or insect injury (peach catfacing, beady wart). There is the possibility that an endogenous hormonal imbalance exists in conjunction with high N-P-K. Because root pruning reduced the incidence of nectarine pox by $60 \%$, we suggest that root-produced hormones (cytokinins) may play a role in the development of nectarine pox. While current economic losses from this disorder are not sufficient to generate extensive studies, our work suggests that additional research directed at the influence of plant nutrients and hormones on the expression of the disorder would be appropriate.

\section{Literature Cited}

Baugher, T.A. and S.S. Miller. 1991. Nectarine pox a disorder of nectarine fruit. HortScience 26:310.

Blanco, A. 1988. control of shoot growth of peach and nectarine trees with paclobutrazol. J. Hort. Sci. 63:201-207.

Dann, I. R., R.A. Wildes, and D.J. Chalmers. 1984. Effects of limb girdling on growth and development of competing fruit and vegetative tissues of peach trees. Austral. J. Plant. Physiol. 11:49-58.

Ferree, D.C. 1989. Growth and carbohydrate distribution of young apple trees in response to root pruning and tree density. HortScience 24:6265.

Fernandez-Escobar, R., R. Martin, P. Lopez-Rivares, and M. Paz Suarez. 1987. Girdling as a means of increasing fruit size and earliness in peach and nectarine cultivars. J. Hort. Sci. 62:463-468

George, A.P. and R.J. Nissen. 1987. Effects of paclobutrazol (PP333) on vegetative and floral development of 'Fla 6-3' and 'Sunred' nectarines. Acta Hort. 199:173-178.

Hayden, R.A. and F.H. Emerson. 1984. The effect of time of pinning and other factors on early yields of 'Redhaven' and 'Biscoe' peach. Compact Fruit Tree 17:118-121.

Lipe, J.A. 1988. Peach tree girdling, p. 540-545. In: N.F. Childers and W.B. Sherman (eds.). The peach. Horticultural Publications, Gainesville, Fla.

Marini, P.P. and D. Rossi. 1985. A partial economic analysis of three pruning treatments on mature peach trees. HortScience 20:242-243.

Rem, C.R. and D.C. Ferree. 1985. Time and severity of summer pruning influences on young peach tree net photosynthesis, transpiration and dry weight distribution. J. Amer. Soc. Hort. Sci. 110:455-461.

Schupp, J.R. and D.C. Ferree. 1988. Effects of root pruning at four levels of severity on growth and yield of 'Melrose'/M.26 apple trees. J. Amer. Soc. Hort. Sci. 113:194-198, 